\title{
The role of the teacher librarian in the bookless library: information literacy and resource creation
}

\author{
James E Herring, PhD \\ School of Information Studies, \\ Charles Sturt University, Wagga Wagga, \\ jherring@csu.edu.au
}

\begin{abstract}
This modified Delphi study examined the views of the leaders of Australia's teacher librarian associations on the bookless school library i.e. a library with no printed books or other printed material. Interviews were used to gather data on the participants' views of what a bookless school library might look like, and what the role of the teacher librarian would be in relation to information literacy and resource creation. Results showed that a bookless school library would contain flexible learning spaces and be a learning commons in the school, which made use of a range of advanced technologies, including interactive walls. The roles of the teacher librarian as information literacy leader and as resource creator would be more important than today.

\section{Introduction}

While there has been some debate about the increasing digitisation of school libraries, there has been no research conducted on the implications for teacher librarians of the future school library, which has no printed books/journals/newspapers. This is an important area for school librarianship as the development of the bookless school library is very likely to change the role of the teacher librarian. The topic of the bookless school library is wide ranging, and includes possible changes in nomenclature for the library and the librarian, in the status of the teacher librarian, and in the services provided to the school community. This Delphi study sought to examine and interpret the views of the leaders of Australia's teacher librarian associations on the bookless school library in a range of areas. In this paper, the appearance of the bookless school library, and the role of the teacher librarian in relation to information literacy, and resource creation, will be examined. It is hoped that this paper will engender wide discussion on the future of the school library.
\end{abstract}

\section{Areas of exploration}

As this study adopts a grounded theory approach, areas of exploration, as opposed to research questions, are identified. The areas of exploration for this study are the views of the leaders of Australia's teacher library associations on:

- The projected physical appearance of the (printed) bookless school library

- The role of the teacher librarian in relation to information literacy in the bookless school library

- The role of the teacher librarian in relation to resource creation in the bookless school library

\section{Literature review}

While there is a growing literature on what are termed 'virtual' school libraries, authors such as Kuhlthau, Goodin and McNally (1996), Cohen (2010), Farmer (2005) and Ash (2010) discuss school libraries which have virtual aspects, but still contain printed book/journal services to students. A more detailed examination of potentially bookless school libraries is provided by Lamb and Johnson (2008 and 2010) who viewed the school library as a 'a twenty-first century laboratory for learning' and identified a range of roles for the teacher librarian, including technology specialist, 'teacher leader' and collaborative colleague. The key aspects covered by Lamb and Johnson (2010) included the creation of 'fluid environments' in which a range of media are used by students, who use digital learning resources; the exploitation of a wide range of webbased resources by students creating e-projects in schools; the use of e-books by students; virtual learning experiences available to students on the web; collaboration between teachers and teacher librarians to create e-resources in schools; and a strategic approach to integrating technology into the school curriculum. 
Valenza (2011) outlined a range of abilities which teacher librarians require to develop virtual libraries. These abilities include learning to use publishing platforms, developing e-pathfinders, being an expert searcher, having a grasp of the issues relating to intellectual property, and exploiting a range of Web 2.0 tools. Valenza (2011) appeared to assume that teacher librarians will be self taught, and does not refer to how teacher librarians will achieve these abilities, for example via in-service training. An example of a proposed bookless school library is addressed in a newspaper article (Abel 2009) and on a blog (Meg H 2009). Abel (2009) reported on a proposal in New England library to replace printed books and journals with e-books and e-journals. One of the arguments put forward by the school was that the workplace into which students would go after school, would most likely be a print-free environment. Meg H (2009) argued that while a bookless school library would suit some schools, students in poorer schools - many of whom lacked web access at home - would not benefit. The subject of print free libraries is not addressed in the formal school library literature in any depth.

An extensive literature on information literacy in the school context examined aspects such as definitions of information literacy, teaching information literacy skills, information literacy models, and information literacy research in schools (Kuhlthau 2004, Herring 2006, 2010 and 2011, Limberg, Alexandersson, LantzAndersson and Folkesson 2008, Lundh and Limberg 2008). There appears to be no literature relating to information literacy in a bookless school library. A similar picture emerges in relation to the role of the teacher librarian as resource creator. Whereas authors such as Valenza (2007), McKenzie (2010) and Herring (2011) discuss the creation of e-resources by teacher librarians, this is not in the context of a bookless library.

\section{Methodology}

This study takes the form of a modified Delphi study within the framework of a constructivist grounded theory approach. This approach (Charmaz 2006, Bryant and Charmaz 2007) implies that the researcher undertakes the study by identifying areas to explore, rather than constructing research questions, and therefore takes a more open approach to the study. Thus the researcher does not have preconceived ideas about what the study's participants' views are likely to be, and seeks to develop categories which represent the views of the participants. A Delphi study (Skulmoski, Hartman and Krahn 2007) seeks the views of experts in a particular field in relation to a topic and attempts to identify areas of agreement and disagreement amongst the experts. Most Delphi studies begin with a questionnaire which is followed up by subsequent questionnaires and/or interviews (Hsu and Sandford 2007), until a consensus has been reached or there are no further changes in the opinions of the group. This study uses a modified Delphi technique, in that interviews are used instead of questionnaires, and the follow-up takes the form of asking participants to respond to the researcher's interpretation of the interview data. There is no intention in this study to seek a consensus. Interviews (Johnson and Christensen 2010) are an established technique used in educational research, but need to be carefully planned and conducted in order to gain quality information from respondents. In this study 14 teacher librarians were interviewed, out of possible total of 18 . These teacher librarians are leaders of the national, state and territory teacher librarian associations in Australia. The researcher contacted all the teacher librarian associations and requested interviews with two member of the association's committee, where possible including the president or vice president of the associations. Two of the nine associations did not participate in the interviews. For this modified Delphi study, the participants are seen by the researcher as potential experts, because of their leadership positions. The interview questions (see Appendix 1 for full list of questions. Questions 1, 3 and 6 are addressed in this paper) focused on the participant's views of their vision of a bookless school library. The study did not seek the participants' views on whether or when bookless school libraries might exist in the future.

The interview data was analysed using constructivist grounded analysis (Charmaz 2006, Bryant and Charmaz 2007). The researcher used initial and focused coding (Charmaz 2006) to identify categories which are discussed below.

\section{Results}

The results of the study are outlined in relation to: the appearance and design of the bookless school library; the role of the teacher librarian in developing information literacy in a bookless school library; the role of the teacher librarian as resource creator in a bookless school library. This study is qualitative in nature and therefore, there is no intention to present detailed numbers or percentages relating to the interviewees' responses. The terms large majority, majority, minority, and small minority are used to indicate the breadth of responses. 


\section{The appearance and design of the bookless school library}

The participants were asked to consider what a bookless school library would look like when one walked through the door of the library. A large majority of interviewees made the point that the school library would have a physical as well as a virtual presence in the school, and a minority argued that the school library would be present - virtually - in all areas of the school, and in much more depth than at present. A small minority of respondents used the term learning commons or creative commons to describe the bookless school library. One respondent referred to a learning commons as 'a place that can enhance crossdisciplinary learning and social interaction'. All respondents agreed that the library would be made up of flexible spaces, possibly with modular furniture. Spaces could be used for whole class, group or individual activities, including class lessons, group research and discussion, and individual study or relaxation.

All respondents also agreed that a key visual feature of the bookless school library would be interactive displays, with the majority stating that interactive walls would present students and staff with dynamic displays. A small minority referred to smart tables, which students could use to view 3D displays e.g. of films, plays or scientific experiments. The interactive walls would be used to display e-books and e-resources, both curricular and recreational, and students would be able to use touch screen (a minority mentioned voice activation) features to navigate the resources. A majority argued that students would also be able to download the content of the interactive walls, depending on copyright. One interviewee argued that schools would lose 'that tangibility that you have in today's libraries', because of the absence of printed books. Other features cited by respondents included interactive bulletin boards, docking stations and online promotion of particular e-resources relating to current school projects.

\section{The role of the teacher librarian in developing information literacy in a bookless school library}

There was a wide range of topics referred to by the interviewees. The key aspect on which all respondents agreed was that information literacy would be more important in a bookless school library, because of the increased quantity and variety of e-resources which students would be accessing. All respondents also agreed that the role of the teacher librarian, as information literacy leader in the school, would be a key element of the school's learning strategy. A majority of interviewees stressed that the teacher librarian would also have an important role in providing in-service sessions for teachers on aspects of information literacy. A minority highlighted the ethical use of information as being important in a bookless library, where students would be using a range of easily downloaded learning resources. Other aspects of information literacy which respondents noted were conceptual understanding of information literacy by students, cybersafety in schools, collaboration with teachers, and digital citizenship.

There was less agreement on whether schools might develop information literacy advice which would be provided by a virtual teacher librarian. A minority of respondents argued that developments in technology would allow for the creation of a virtual presence, which would not only give students online access to information literacy advice, but which would be able to answer students' queries online. Other respondents were either uncertain about such a development being possible, or could not see any benefit in the provision of a virtual teacher librarian, as they doubted whether students would use such a facility.

\section{The role of the teacher librarian as resource creator in a bookless school library}

There was general agreement that teacher librarians should be more involved the creation of integrated learning resources in schools. All respondents agreed that teacher librarians should extend their role of resource provider into that of resource creator. Key factors highlighted by respondents included the expertise needed to create meaningful learning resources, including knowledge of e-learning in schools, the time needed to create resources, and the need for teacher librarians to collaborate with teachers to create resources which would use advanced technologies (e.g. web 3.0 and web 4.0). A minority saw the role of the teacher librarian changing more to that of an educational designer in the school.

\section{Discussion}

School libraries which have no printed materials, such as books and journals, are extremely rare at the present time. This study attempted to highlight some of the key aspects which might affect the role of the teacher librarian in the event of bookless school libraries becoming the norm. There were a range of views on what a bookless school library might look like, and the views expressed by the respondents correlated with the views of Lamb and Johnson (2010) and Valenza (2011), particularly in highlighting the need for flexibility of spaces, and the use of a range of advanced technologies. The discussion on interactive walls identifies advanced possibilities for school libraries, although there was no evidence of research in the education literature. 
Most respondents view the role of the teacher librarian in relation to information literacy as a continuation of the role played by many teacher librarians today, as discussed by Herring (2010 and 2011), and Limberg, Alexandersson, Lantz-Andersson and Folkesson (2008). A new element in this study is the discussion on the possibility of having virtual teacher librarians i.e. not teacher librarians who answer queries online, but machine-based, intelligent 'librarians', providing a virtual service to students and staff.

The role of the teacher librarian as resource creator was also viewed by respondents as developing from the examples of a small minority of today's teacher librarians, who undertake such a role in creating not just epathfinders, but integrated learning packages, in collaboration with teachers. This reflects the views of Herring (2011) and McKenzie (2010). One new aspect discussed in this study is whether the teacher librarian's role might change from being primarily a resource provider, to that of a resource creator or educational designer.

\section{Conclusion}

This study is intended to promote wide discussion on the potential role of the teacher librarian in a print-free school library. This debate will be important, as there appear to be many people in education who might take the view that, as librarians are viewed mainly in relation to printed books, a bookless school library would not necessarily require a professionally qualified person to manage the functions and services of the school library.

\section{Three key learnings:}

- Teacher librarians need to debate their possible role in a print-free school library environment

- Teacher librarians need to be aware of future trends in the technologies which might be developed in a bookless school library

- Teacher librarians need to consider the implications for their role in schools where e-learning becomes more widespread

\section{References}

Abel, D. (2009) Welcome to the library. Say goodbye to the books. Boston Globe. September 4.

Ash, K. (2010). School libraries seek relevance through virtual access. Education Week, 29 (21), 10-11.

Bryant, A. \& Charmaz, K. (Eds.) (2007). The Sage handbook of grounded theory. London, England: Sage.

Charmaz. K. (2006). Constructing grounded theory: a practical guide through qualitative analysis. London, England: Sage.

Cohen, S. (2010) Growing a knowledge building center. Teacher Librarian, 37(5), 37-41.

Farmer, L. (2005) Virtual reference service for K--12 students. Knowledge Quest, 33(3), 22-24.

Herring, J. (2011) Improving students' web use and information literacy: A guide for teachers and teacher librarians. London: Facet Publishing.

Herring, J. (2010). School students, question formulation and issues of transfer: a constructivist grounded analysis. Libri 60, 218-229.

Herring, J. 2006. A critical investigation of students' and teachers' views of the use of information literacy skills in school assignments. School Library Media Research (9). Retrieved from http://www.ala.org/ala/aasl/aaslpubsandjournals/slmrb/slmrcontents/volume9/informationliteracy.cfm

Hsu, C-C and Sandford, B. (2007). The Delphi Technique: Making sense of consensus. Practical Assessment Research \& Evaluation, 12(10). Retrieved from http://pareonline.net/getvn.asp?v=12\&n=10

Johnson, B. \& Christensen, L. (2010). Educational research: Quantitative, qualitative and mixed approaches. ( ${ }^{\text {th }}$ ed.), Thousand Oaks, CA: Sage Publications. 
Kuhlthau, C. 2004. Seeking Meaning: A process approach to library and information services. $2^{\text {nd }}$ ed., Santa Barbara, CA: Libraries Unlimited.

Lamb, A. \& Johnson, L. (2008) School library media specialist 2.0: a dynamic collaborator, teacher, and technologist. Teacher Librarian, 36(2), 74-78.

Lamb, A.\& Johnson, L. (2010) Divergent Convergence Part 2: Teaching and Learning in a Transmedia World. Teacher Librarian 38(1), 64-69.

Limberg, L., \& Alexandersson, M., Lantz-Andersson, A. and Folkesson, L. (2008). What matters? Shaping meaningful learning through teaching information literacy (1). Libri, 58, 82-91.

Lundh, A. \& Limberg, L. (2008). The role of the pedagogue in pupils' construction of information literacy. Libri, 58 (2), 92-101.

McKenzie, J. (2010) Why we still need libraries and librarians. From Now On, 19 (4). Retrieved from http://fno.org/mar2010/still.html

Meg H. (2009). The bookless school library. Classroom 2.0. Retrieved from http://www.classroom20.com/profiles/blogs/the-bookless-school-library

Skulmoski, G., Hartman, F. \& Krahn, J. (2007). The Delphi method for graduate research. Journal of Information Technology Education 6. Retrieved from http://jite.org/documents/Vol6/JITEv6p001021Skulmoski212.pdf

Valenza, J. (2011) Fully loaded: Outfitting a teacher librarian for the $21^{\text {st }}$ century. School Library Journal,

January 1. Retrieved from http://www.schoollibraryjournal.com/slj/printissuecurrentissue/888448427/fully_loaded_outfitting_a_teacher.html.csp

Valenza, J. (2007) Ten reasons why your next pathfinder should be a wiki. Retrieved from http://blog.schoollibraryjournal.com/neverendingsearch/2007/06/20/ten-reasons-why-your-nextpathfinder-should-be-a-wiki/

\section{Biographical Note}

Dr James E Herring is a lecturer in teacher librarianship at Charles Sturt University, Australia. He was formerly head of the Department of Information Management at Queen Margaret University, Scotland. James is the author of ten books on teacher librarianship, information literacy and ICT in schools, and of many research and professional articles. James teaches from his home in Scotland for 10 months of the year, and spends 2 months in Australia.

\section{Statement of Originality}

This statement certifies that the paper above is based upon original research undertaken by the author and that the paper was conceived and written by the author(s) alone and has not been published elsewhere. All information and ideas from others is referenced. 


\section{Appendix}

\section{Interview questions}

1. Please explain to me what you think a bookless school library will look like in physical terms.

2. Please explain to me what technologies you think will be used in a bookless school library.

3. In a bookless library, what do you think the teacher librarian's role will be in relation to information literacy?

4. In a bookless library, what do you think the teacher librarian's role will be in relation to the selection of digital resources?

5. In a bookless library, what do you think the teacher librarian's role will be in relation to the organisation of, and access to, digital learning resources?

6. In a bookless library, what do you think the teacher librarian's role will be in relation to the creation of e-learning resources for students in the school?

7. What changes do you think will be needed in the education of teacher librarians who are likely to manage a bookless library?

8. Do you have any other comments on the likely role of the teacher librarian in a bookless library? 